\title{
VIEIRA: UMA LIÇÃO DE RETÓRICA
}

Vera Lúcia de Carvalho Casa Nova Universidade Federal de Minas Gerais

(...) a Retórica para a salvação dos índios brasileiros com o fim de persuadir o rei de Portugal e a doxa portuguesa a mudar de procedimentos com relação aos processos de colonização existentes aqui no século XVI"1.

ermão eminentemente político contra os colonos que escravizavam índios, e contra os dominicanos e seu "estilo" de doutrinar, o da Sexagésima mostra a vocação original da retórica - como a teoria geral do discurso persuasivo - em uma verdadeira aula sobre os processos da argumentação.

Guardando a tradição vinda de Aristóteles, ou seja, docere (ensinar, informar); movere (comover os sentimentos) e delectare (encantar, seduzir), esse orador do púlpito barroco prega e se propõe a difundir a palavra de Deus, desejando convencer o auditório de haver outras retóricas com fins escusos que não o de semear sua palavra.

O orador Vieira constrói seu discurso no intertexto da parábola do Semeador em escuta atenta ao Evangelho, através das analogias. Para tal desconstrói Mateus, XIII, 3 recortando signos importantes para seu objetivo. Traduz e interpreta, tendo na interpretação seu maior trunfo, e sua principal prática lingüística.

Ao pé da letra os sentidos são vigorosamente trabalhados: "Para quem lavra com Deus até o sair é semear, porque também das passadas colbe este fruto".

${ }^{1}$ Todas as citações pertencem ao texto Sermão da Sexagésima. Clássicos. São Paulo: Agir, s/d. 
Atento a tudo, Vieira chama a atenção para aqueles que saem e aqueles que ficam em Portugal em posições que se assemelham ao pensar na palavra a ser semeada.

$\mathrm{Na}$ prática do discurso religioso reproduz-se a voz de Deus, voz que deve plasmar todas as outras vozes. Vieira é um agenciador de tal palavra e em nome dela arma, organiza as estratégias dos signos e dos pensamentos - signos.

Em Vieira o signo é interpretado para compreensão da idéia que ele veicula. O signo é um significado derivado da coisa, através de um processo, chamado de representação. A leitura do signo deve ser a mesma de sua produção - O Deus é o Deus do Evangelho que deve ser interpretado pela luz do Evangelho. Do signo ao signo e assim por diante ad infinitum, até chegar ao significado final Deus. Um dos percursos da metafísica do signo. Esse processo por meio do qual um signo dá à luz um outro, o filósofo Peirce chamou de "pura retórica" 2 .

Jogando com o sentido próprio (a denotação) e o sentido figurado (conotação), Vieira recorre ao latim para argumentar com eficácia e instituir seu lugar e seu espaço ${ }^{3}$ de poder. Observe-se o que acontece com o jogo da homonímia. "os de cá, achar-vos-eis com mais Paço; os de lá, com mais passos: Exiit seminare".

Ludicamente, no sentido do trabalho da língua, Vieira mostra a concepção de como as palavras estão ancoradas no auditivo e no intencional, demonstrando que à intersecção dessas duas categorias os signos lingüísticos se constituem e são interpretados do ponto de vista da ironia, como no exemplo citado.

No Sermão da Sexagésima a retórica, essa língua artificial, tem regras preparadas para capturar as idéias: o dispositio, que separa, no discurso, um princípio, um meio e um fim; o silogismo, com suas

${ }^{2}$ De man, Paul. Alegorias da leitura. Rio: Imago, 1996

3 Diferença marcada por M. de Certeau: "O espaço é um lugar praticado", p.202, v.1. A invenção do Cotidiano. 
duas premissas, e a conclusão. É a dialética, graças a qual tudo parece natural e racional.

A imagem do semeador é a que organiza o discurso da influência. Vejamos alguns passos:

$1^{\circ}$ a idéia do semeador é próxima da realidade do ouvinte; assim ela poderá surtir o efeito desejado, pois a qualidade do auditório é que determina a da argumentação. E Vieira sabia para quem discursava (conhecimento do auditório);

$2^{\circ}$ o conhecimento do Evangelho pelos ouvintes;

$3^{\text {o }}$ os valores abstratos e concretos que se sucedem na base da argumentação.

Uma parte do trigo caiu entre espinhos e afogaram-no os espinhos...

outra parte caiu sobre pedras e secou-se nas pedras por falta de umidade outra parte caiu no caminho e pesaram-no os homens e comeram-no as aves

$4^{\text {o }}$ Afirmações peremptórias desempenham papel importante, vigor da língua, vigor retórico. O discurso de Vieira se constrói como verdade, não sua, mas do outro, aquele que por ser considerado determinação de todas as coisas engloba todas as falas dos bons pregadores.

Os ouvintes, ou são maus ou são bons: se são bons, faz neles grandes frutos a palavra de Deus; se são maus, ainda que não faça neles frutos, faz efeito

Fazer efeito, esse o objetivo do orador.

Lembro Aristóteles na Arte Retórica quando diz ser a Retórica mais um discurso sobre a "essência do orador", ou mesmo Cícero (De Oratore) quando enuncia uma série de qualidades necessárias ao orador.

A techné em Vieira, qualidade racional criadora, não pode ser resumida unicamente à forma, ou mesmo ao exclusivamente literário, pois a tecnicização da retórica se liga à pedagogia, ao ensino jesuítico nas escolas, nos espaços de catequese no Brasil. 
Todos os tratados de Retórica encontrados na Europa possuíam (possuem) esse caráter: eram destinados ao ensino de Retórica, onde se aprendia a reconhecer e depois utilizar sistematicamente as figuras.

A aula de Retórica dada por Vieira enuncia, por esse discurso pedagógico que aí se encontra, as diversas técnicas para o efeito de persuadir. Repetições, anáforas, metáforas, ampliações e todo o jogo de linguagem são de caráter normativo.

As figuras de estilo, hoje, pouco estudadas nas escolas, não são ornamentos em seu discurso, como o são em Bossuet ou Pascal. Funcionam dentro de sua máquina retórica, visando em seu aspecto geral o aprendizado das Escrituras.

Sabeis, cristãos, por que não faz fruto a palavra de Deus? - Por culpa dos pregadores. Sabeis, pregadores, porque não faz fruto a palavra de Deus? Por culpa nossa

No pregador podem-se considerar cinco circunstâncias: a pessoa, a ciência, a matéria, o estilo, a voz. A pessoa que é, a ciência que tem, a matéria que trata, o estilo que segue, a voz com que fala. Todas essas circunstâncias temos no Evangelho

O argumento da culpa e a alusão freqüente ao Evangelho delineia o mapa ideológico que segue o que é traçado pela palavra.

Chamando a atenção para a prática e não para a teoria da retórica, Vieira sublinha a ação e direciona seu discurso para discutir o estilo de sua época - o que ele chama de "cultismo".

Será por ventura o estilo que hoje se usa nos púlpitos? Um estilo tão empeçado, em estilo tão afetado, um estilo tão encontrado a toda a arte e a toda a natureza?...

Que diferente é o estudo violento e tirânico que hoje se usa?

Esse "desventurado estilo" que faz obscurecer as idéias e as palavras que devem ser "muito diferentes e muito claras", faz Vieira mostrar como deve ser a "matéria" e a "forma" do sermão.

Infletindo-se sobre seu próprio discurso argumentativo, o autor mostra aos seus ouvintes como fazer um sermão: 
Há de tomar o pregador uma só matéria, há de defini-la para que se conheça, há de dividi-la para que se distinga, há de prová-la com a Escritura, há de declará-la com a razão, há de confirmá-la com o exemplo, há de amplificá-la com as causas, com os efeitos, com as circunstâncias, com as conveniências que se hão de seguir, com os inconvenientes que se devem evitar;

há de responder às dúvidas, há de satisfazer às dificuldades,

há de impugnar e refutar com toda força da eloqüência os argumentos contrários, e depois disto

há de colher

há de apertar

há de concluir, persuadir, há de acabar. Isto é sermão, isto é pregar...

Esta é a arte retórica do sermão de Vieira, que em nada ficaria a dever à tradição de retórica aristotélica ou à obra de Quintiliano.

A matéria do pensamento, da frase, da palavra adquire movimento, fundamentando a máquina retórica do convencimento e da comoção. A techné de Aristóteles é deslocada para a Ratio barroca cristã.

Prova, exemplum ( indução retórica); entimema (dedução), figuras exemplares (imago) organizam no sermão, a retórica de Vieira.

A retórica da ordem racional clássica passa à retórica barroca, onde o dogma se encontra como grande intertexto. Tudo se encontra (lá) nas Escrituras, e é essa retórica que deverá servir e dar como exemplo-modelo-imago a palavra de Deus e sua própria imagem.

A capacidade de persuadir parte daí - de sua estratégia verbal. Consciente dos recursos de seu comportamento persuasivo, ele habilmente explicita (seu) um método de trabalho.

Memória e/ou entendimento também é importante chave para a técnica retórica. Chamando a atenção dos pregadores que usam 
o gesto para convencer. Para Vieira, a retórica do gesto é a retórica vazia.

Energia que ultrapassa o limite do verbo, "o texto escrito para ser oral traduz uma verdadeira epifania da voz viva, apesar dele e em aparente contradição com seu status de escritura".

Em Vieira: "As palavras de Deus, pregadas no sentido em que Deus as disse, são palavras de Deus; mas pregadas no sentido que nós queremos não são palavras de Deus, antes podem ser palavras do Demônio".

Não há lugar, assim, para abertura do sentido, mas o Sentido, aquele que vem da voz de Deus - Vieira seu tradutor - Hermes cristão - Hermenêutica cristã - metafísica do signo.

A retórica parece transformar-se em Hermenêutica. Atrelado à razão barroca, Vieira mostra um raciocínio retórico argumentativo que ensina a verdade das escrituras. Vieira assegura o sentido, é clara a intenção de significação que pré-existe a seu discurso. O signo é assim, representação, origem da Verdade do Sentido, centrado no axioma de um significado transcendental.

Fazendo do sermão um acontecimento político-ideológico dentro da própria Igreja, Vieira institui uma verdadeira pragmática no discurso do pregador, exigindo intervenção na ação do outro, responsabilizando-o pela decisão a ser tomada, ou seja, sobre a moral da responsabilidade de colonização/doutrinação dos índios brasileiros. "O pregar não é recitar. As razões próprias nascem do entendimento, as alheias vão pegadas à memória, e os homens não se convencem pela memória, senão pelo entendimento".

Algumas notícias sobre a dicção do sermão nos são reveladas: "Antigamente pregavam bradando, hoje pregam conversando. Antigamente a primeira parte do pregador era boa voz e bom peito. E verdadeiramente, como o mundo se governa, tanto pelo sentido, podem às vezes mais os brados que a razão..."

${ }^{4}$ Zumthor, P. A letra e a voz. São Paulo: Cia das Letras, 1993. 
A retórica de Vieira veste a língua, como a roupa do português vestiu o índio. Resta o teatro - a teatralização do verbo - a encenação, a performance. Vieira parece ter compreendido a retórica do gesto.

Assim é a aula de Retórica em Vieira. Fechada semioticamente por parte do seu emissor - o seu enunciador, mas demonstrando que a persuasão existe enquanto é ação da linguagem sobre a doxa, pondo em evidência a função performativa de linguagem, essa aula exibe letra e voz num esforço concentrado de dizer o Verbo.

O trajeto de sua vida mostra a resposta dada a ele pelo poder eclesiástico:

1655 - Obtém a Lei da Liberdade dos Índios;

1661 - Expulso do Maranhão com outros jesuítas;

1662 - Desterrado para o Porto;

1665 - Preso pela inquisição;

1667 - Palavra cassada por sentença do Santo Ofício, com pena de reclusão;

1675 - O papa isenta-o da Inquisição;

1681 - Regressa à Bahia.

Enfim, dentro da história da literatura, Pe. Antonio Vieira revela-se uma figura cuja perplexidade diante da violência acabou por levá-la ao confronto dentro de sua instituição - a Igreja.

Não estaria aí a verdadeira performance de sua retórica? 


\section{Resumo}

Trata-se de uma análise proposta pelo texto de Vieira a partir do jogo retórico.

\section{Résumé}

Il s'agit d'une analyse proposée par le texte de Vieira à partir du jeu rétthorique. 